Gazi University
Journal of Science
http://dergipark.gov.tr/gujs

\title{
Optimization of Endo-Pectinase and Pectin Lyase Production from Wheat Bran by Bacillus pumilus using Response Surface Methodology
}

\author{
Ozlem TEPE*(i), Arzu Y. DURSUN \\ Firat University, Faculty of Engineering, Department of Environmental Engineering, 23119, Elazig, Turkey
}

Highlights

- This paper focuses on pectin lyase and endo-pectinase synthesis from wheat bran by Bacillus pumilus.

- RSM was employed.

- Optimum conditions for enzyme production were obtained.

\begin{tabular}{l} 
Article Info \\
\hline \\
Received: 09 Oct 2020 \\
Accepted: 30 Nov 2020 \\
Keywords \\
Endo-pectinase \\
Optimization, \\
Pectin lyase, \\
Response surface \\
methodology (RSM), \\
Wheat bran
\end{tabular}

\section{INTRODUCTION}

Pectic substances are complex polysaccharides of higher plants and are found mainly in the middle lamella between cells in tissues [1]. Pectin, protopectin, pectinic acid and pectic acid are basic types of pectic substances. Pectinases are clusters of enzymes that break down pectic substances by various mechanisms. They are classified as protopectinases, esterases and depolymerases, according to the attack mechanism on the galacturonan part of the pectin molecule. Protopectinases are involved in the degradation of insoluble protopectin and provide the formation of highly polymerized soluble pectin. Esterases remove methoxy esters by catalyzing the de-esterification of pectin. Depolymerases are the enzymes that act on pectic substances by hydrolyzing the glycosidic linkages between galacturonic monomers or cleaving $\alpha-1,4-$ glycosidic linkages by trans-elimination [2-4]. Pectinolytic enzymes are among the first enzymes that were used in households. Their industrial usage began in 1930 with the production of fruit juice and wine [5]. Today, pectinolytic enzymes account for approximately $25 \%$ of the world's manufacturing of food enzymes. Pectinases have widespread usages in the textile, paper, food manufacturing, tea and coffee fermentation, olive oil industries and in the treatment of pectic wastewater [6,7]. They are used as juice yield and color enhancers, clarifies, and in fruit mash treatment in the fruit juice industry [8,9]. They are also used in the clarification of wine [10]. Pectinases are also classified as alkaline pectinases and acidic pectinases according to their usage area. Alkaline pectinase is synthesized efficiently by bacterial sources and are primarily utilized in the textile industries and for pectic wastewater pretreatment occurring from the fruit juice industry. Acidic pectinases produced by fungi are used in the fruit juice industry [4]. 
Two methods of fermentation are used in the synthesis of these enzymes: submerged fermentation (SMF) and solid-state fermentation (SSF) [11]. In SMF, a liquid nutrient medium is used for the cultivation of the microorganisms. On the other hand, SSF includes the production of microorganisms on a solid substrate. The main concerns in enzyme production process are yield, stability, specificity and production cost. The composition of the nutrients is one of the key factors that influences microbial growth and enzyme synthesis [12]. Approximately 30-40\% of the enzyme production costs constitute the fermentation medium [13]. Castilho et. al [14] studied lipase fermentation by Penicillium restrictum using SSF and SMF techniques and reported that the investment cost required for SSF is $78 \%$ lower than that required for SMF. Agricultural residues and food waste such as sugar beet pulp, wheat and corn flour, rice bran and wheat bran can be selected as the solid material for SSF $[15,16]$. This type of waste contains high amounts of carbohydrates and other nutrients. However, if they do not include all the nutrients required for the enzyme production processes, extra carbon or nitrogen sources can be added to improve the fermentation medium [17]. Using these wastes as carbon sources in the manufacturing of enzymes decreases manufacturing costs and helps to solve the problem of disposal. SSF also has other advantages over SMF. For example, the growth medium is very similar to the natural habitat of microorganisms, thus high volumetric productivity and high enzyme yields can be obtained. In addition, the amount of liquid waste produced with SSF is lower than SMF [14].

Wheat bran is an agricultural residue preferred by many researchers. In 2017, the Food and Agriculture Organization of the United Nations announced that the wheat production around the world was $771,700,000$ tons. Approximately 15-20\% (in weight) of wheat is removed as wheat bran. Therefore, in SSF processes, wheat bran is classified as a sustainable by-product. This complex carbohydrate can easily be utilized by microorganisms that obtain pectinases. The use of such an abundant material to obtain a value-added enzyme can also assist to overcome the pollution issue [12].

In fermentation processes, the effects of each parameter on the system can be examined one by one with the classical optimization methods. However, the optimization of media components using such methods has several drawbacks. For example, these methods require a lot of experimentation, which would take a lot of time. In addition, in multivariable systems, these methods are sometimes not sufficient to explain the interactions between the variables. Therefore, in recent years, classical methods have been replaced by statistical methods. One of the most commonly used statistical methods is the response surface methodology (RSM). It involves factorial designs and regression analysis to plan multifactor experiments and solve multi-variate equations $[13,18]$. It enables the planning of multifactor experiments, determination of optimum experimental conditions, constitution of empirical models (equations) and assessment of the importance of independent variables on the desired variable response [19]. It has been commonly used for optimization in the fields of biochemical and chemical engineering to produce enzymes, determine the composition of cultivation media, conditions of enzymatic hydrolysis and parameters for the polymers and food production $[18,19]$. In this study, wheat bran was selected as the carbon source and supplemented with ammonium sulphate $\left(\mathrm{NH}_{4}\right)_{2} \mathrm{SO}_{4}$ and yeast extract. $\mathrm{RSM}$ was employed to examine the effects of the wheat bran, yeast extract and ammonium sulphate concentrations on the synthesis of pectin lyase and endopectinase and the dosages of these nutrients were optimized.

\section{MATERIAL METHOD}

\subsection{Bacterial Strain and Growth Conditions}

The Bacillus pumilus (NRRL B-212), which was provided from USA (National Center for Agricultural Utilization Research) was grown on potato dextrose agar at $30{ }^{\circ} \mathrm{C}$ and then inoculated in the nutrient solution. The production of the microorganism was achieved in a sterilized (autoclaved at $1.1 \mathrm{~atm}$ and 121 ${ }^{\circ} \mathrm{C}$ ) growth medium. The composition of this medium and the culture conditions were explained in the previous study [20]. After incubating, the microorganisms were transmitted into the pectinase fermentation medium (in a 1:10 ratio). 


\subsection{Production of Endo- Pectinase and Pectin Lyase with Agricultural Wastes}

Wheat bran used in the SSF studies was obtained locally. Firstly, it was washed then dried in an oven at 60 ${ }^{\circ} \mathrm{C}$ for $24 \mathrm{~h}$. The dried materials were then milled and sized (20-100 mesh). The solid material was placed Erlenmeyer flasks $(250 \mathrm{~mL})$ for enzyme production. The flasks were then sterilized for 15 minutes at a temperature of $121{ }^{\circ} \mathrm{C}$ and cooled to room temperature. The tap water was used for hydrating the dried materials. After inoculation with liquid culture $(10 \%, \mathrm{v} / \mathrm{v})$, enzyme production experiments were conducted at $30^{\circ} \mathrm{C}, \mathrm{pH} 8$ and $150 \mathrm{rpm}$. The enzyme activity measurements were performed for the samples centrifuged at $5000 \mathrm{rpm}$ for 5 minutes.

\subsection{Determination of Pectin Lyase and Endo-Pectinase Activities}

The thiobarbituric acid method defined by Nedjma et al. [21] was used for the assay of pectin lyase activity. The method was explained in detail in our previous study [22].

Endo pectinase activity was measured viscosimetrically using a vibroviscometer (SV10, Sine Wave Vibro Viscometer, A\&D Engineering) [23]. The reaction mixtures consisted of $1 \mathrm{~mL}$ of enzyme solution and 19 $\mathrm{mL}$ of $0.5 \%(\mathrm{w} / \mathrm{v})$ apple pectin in a $0.05 \mathrm{M}$ glycine- $\mathrm{NaOH}$ buffer $(\mathrm{pH} 10)$. This solution was heated at 30 ${ }^{\circ} \mathrm{C}$ for $15 \mathrm{~min}$. After incubation, the reduction in viscosity was monitored by a vibroviscometer. Under these conditions, the enzyme quantity reduced the initial solution viscosity by $50 \%$ per minute was determined as one unit of endo pectinase activity.

\subsection{Optimization of Enzyme Production Process Parameters}

In the present study, the relationship between the substrates and enzyme production was investigated using RSM. As a full factorial matrix, a central composite design (CCD) was applied to reveal the parameters influencing enzyme activity. According to a full factorial design, the value of $\alpha$ is equal to $(2 \mathrm{k})^{1 / 4}$. In this study, the values of $\mathrm{k}$ and $\alpha$ were equal to 3 and 1.68179, respectively. Concentrations of wheat bran, $\left(\mathrm{NH}_{4}\right)_{2} \mathrm{SO}_{4}$ and yeast extract were used as numeric factors. To obtain a second order response surface, their quantities were changed at five different levels $(-\alpha,-1,0,+1,+\alpha)$ (Table 1$)$. The maximum and minimum values of the substrate concentrations were selected according to the results of the initial tests. A total of 20 experiments were planned using this full factorial matrix. These experiments contained six center points, six axial points and eight factorial points with six replicates around center point (Table 2). Design Expert software Ver 7.0 (Stat Ease Inc.) statistical package was used to calculate and analyze of the second-order polynomial coefficients.

Table 1. Levels of the parameters in CCD

\begin{tabular}{lcccccc}
\hline Independent variables & $\begin{array}{l}\text { Symbol } \\
\text { (concentration, w/v \%) }\end{array}$ & \multicolumn{2}{l}{ Range and levels } & & & \\
\cline { 3 - 7 } & code & $-1.682(-\alpha)$ & -1 & 0 & +1 & $+1.682(+\alpha)$ \\
\hline Wheat bran & $\mathrm{A}$ & 2.0 & 3.22 & 5.0 & 6.78 & 8.0 \\
Ammonium sulphate & $\mathrm{B}$ & 0.0 & 0.12 & 0.3 & 0.48 & 0.6 \\
Yeast extract & $\mathrm{C}$ & 0.0 & 0.12 & 0.3 & 0.48 & 0.6 \\
\hline
\end{tabular}

\section{RESULTS AND DISCUSSION}

In this study, wheat bran was selected as the carbon source and supplemented with $\left(\mathrm{NH}_{4}\right)_{2} \mathrm{SO}_{4}$ and yeast extract. RSM was applied to examine the effects of the substrate concentrations on the synthesis of pectin lyase and endo-pectinase and dosages of these nutrients were optimized. The concentrations of the substrates were selected as the independent variables. Table 1 shows the levels and the range of these variables, while Table 2 presents the coded values of the factors, design and results of the experiments. The experimental findings showed that the pectin lyase and endo-pectinase activities matched to the secondorder quadratic equation, providing two numerical correlations to predict the enzyme activity responses. The following model equations (Equations (1) and (2), in the coded factors) were proposed for the endo pectinase and pectin lyase activities, respectively: 
Endo-pectinase activity $=+174.50+0.29 A-9.20 B-22.25 C+0.32 A B-3.56 A C+24.27 B C-34.07 A^{2}-$ $5.27 B^{2}-24.49 C^{2}$

Pectin lyase activity $=+26.26-2.15 A-4.74 B-10.72 C-2.16 A B+2.30 A C+4.21 B C-8.01 A^{2}+0.26 B^{2}-1.0$ $C^{2}$.

Table 2. CCD matrix, Response factor results

\begin{tabular}{|c|c|c|c|c|c|c|c|}
\hline \multirow{3}{*}{ Runs } & \multicolumn{3}{|l|}{ Variables } & \multicolumn{4}{|l|}{ Responses } \\
\hline & & & & \multicolumn{2}{|c|}{$\begin{array}{l}\text { Endo-pectinase activity } \\
\text { (U/mL) R1 }\end{array}$} & \multicolumn{2}{|c|}{$\begin{array}{l}\text { Pectin lyase activity }(\mathrm{U} / \mathrm{mL}) \\
\text { R2 }\end{array}$} \\
\hline & A & B & $\mathrm{C}$ & Exp. & Predic. & Exp. & Predic. \\
\hline 1 & -1 & 1 & -1 & 90.61 & 95.27 & 29.67 & 25.90 \\
\hline 2 & +1.682 & 0 & 0 & 93.38 & 78.62 & 9.77 & $8.587 \mathrm{E}-004$ \\
\hline 3 & 0 & 0 & 0 & 167.31 & 174.50 & 23.90 & 26.26 \\
\hline 4 & 1 & 1 & 1 & 85.44 & 100.55 & 6.20 & 4.25 \\
\hline 5 & 0 & +1.682 & 0 & 150.16 & 144.12 & 11.73 & 19.03 \\
\hline 6 & 0 & 0 & 0 & 173.46 & 174.50 & 23.80 & 26.26 \\
\hline 7 & 1 & -1 & -1 & 157.93 & 169.92 & 24.33 & 34.91 \\
\hline 8 & 0 & 0 & 0 & 178.64 & 174.50 & 24.40 & 26.26 \\
\hline 9 & 0 & 0 & -1.682 & 144.98 & 142.65 & 49.07 & 41.47 \\
\hline 10 & 1 & -1 & 1 & 62.14 & 69.76 & 1.73 & 9.64 \\
\hline 11 & 0 & 0 & 0 & 175.08 & 174.50 & 27.80 & 26.26 \\
\hline 12 & -1 & 1 & 1 & 106.15 & 106.44 & 14.73 & 8.29 \\
\hline 13 & 1 & 1 & -1 & 103.56 & 103.61 & 9.43 & 12.67 \\
\hline 14 & 0 & 0 & 0 & 178.64 & 174.50 & 29.87 & 26.26 \\
\hline 15 & -1 & -1 & -1 & 165.70 & 162.87 & 33.40 & 39.49 \\
\hline 16 & -1.682 & 0 & 0 & 80.26 & 77.65 & 3.32 & 7.24 \\
\hline 17 & 0 & 0 & +1.682 & 82.85 & 67.81 & 3.65 & 5.40 \\
\hline 18 & -1 & -1 & 1 & 64.72 & 76.95 & 4.13 & 5.02 \\
\hline 19 & 0 & -1.682 & 0 & 186.41 & 175.08 & 48.13 & 34.98 \\
\hline 20 & 0 & 0 & 0 & 170.87 & 174.50 & 26.80 & 26.26 \\
\hline
\end{tabular}

As can be seen from Equation (1), $A, A B$ and $B C$ had positive influences on the endo pectinase activity, whereas the other parameters had adverse effects. Similarly, $A C, B C$ and $B^{2}$ also had positive influences on the pectin lyase activity.

The significance of these seconder order equations was analyzed statistically using variance analysis. The ANOVA results of models showed that they could be used to navigate the design field (Tables 3-6). The very low P-value $(<0.0001)$ and the F-value $(30.01)$ of model for the endo pectinase activity demonstrated that it was highly significant within a $95 \%$ confidence interval. For the pectin lyase activity, the F-value of model (4.85) indicated that the model was important. The probability of a large Model F-Value due to noise was only $1.07 \%$. A high correlation between the experimental and predicted activity values was indicated by the value of the determination coefficient $\mathrm{R}^{2}$ for the endo-pectinase activity $(0.9643)$. This showed that the regression model explained the relationship between the endo pectinase activity and the wheat bran amount, $\left(\mathrm{NH}_{4}\right)_{2} \mathrm{SO} 4$ and yeast extract concentrations well. In addition, this indicated that $96.43 \%$ of the variation for the endo-pectinase activity was explained by the wheat bran, $\left(\mathrm{NH}_{4}\right)_{2} \mathrm{SO}_{4}$ and yeast extract concentrations and it could not describe only $3.57 \%$ of the variation. The adjusted $\mathrm{R}^{2}$ of 0.9322 was too high to indicate that the it had a high significance [24]. The adjusted $\mathrm{R}^{2}$ arranges the $\mathrm{R}^{2}$ values. If there are a few variables in a model and the sample size is not very large, the $\mathrm{R}^{2}$ may be clearly higher than the adjusted $\mathrm{R}^{2}$. The predicted $\mathrm{R}^{2}$ of 0.7382 and the adjusted $\mathrm{R}^{2}$ of 0.9322 were in reasonable agreement. It had a partially high determination coefficient $\left(\mathrm{R}^{2}=0.8136\right)$ for the pectin lyase activity. When the $\mathrm{R}^{2}$ values are less than 0.75 , models generally show an inadequate definition of experimental data. The determination coefficient for a good model fit should be at least 0.80 [25]. The coefficient of variation $(\mathrm{CV}=8.81 \%)$ for the endo pectinase activity was relatively low. This revealed that the experiments were more accurate and 
reliable. Adequate precision specifies the ratio of signal to noise. It is desired to be greater than 4. In this study, the model ratios for pectin lyase and endo-pectinase were determined as 6.955 and 13.149 respectively. This showed an adequate signal and proved that they can be used to navigate the design space.

Table 3. ANOVA results for endo- pectinase activity

\begin{tabular}{llllll}
\hline Source & Sum of squares & DF & Mean square & F- value & $\begin{array}{l}\text { Probability } \\
(\mathrm{P})>\mathrm{F}\end{array}$ \\
\hline Model & 35944.59 & 9 & 3993.84 & 30.01 & $<0.0001$ \\
Residual & 1330.98 & 10 & 133.10 & & \\
Lack of fit & 1231.91 & 5 & 246.38 & 12.43 & 0.0076 \\
Pure error & 99.07 & 5 & 19.81 & & \\
Corrected total & 37275.57 & 19 & & & \\
\hline
\end{tabular}

$\mathrm{R}^{2}$ : 0.9643, Adj. $\mathrm{R}^{2}$ : 0.9322, Pred. $\mathrm{R}^{2}$ : 0.7382, Adeq. Precision: 13.149

Table 4. Estimates of the model regression for endo- pectinase activity

\begin{tabular}{lccc}
\hline Source & Parameter estimate & F- value & $\begin{array}{c}\text { Probability } \\
(\mathrm{P})>\mathrm{F}\end{array}$ \\
\hline Intercept & & $<0.0001$ \\
$\mathrm{~A}$ & 174.50 & 30.01 & 0.9279 \\
$\mathrm{~B}$ & 0.29 & $8.606 \mathrm{E}-0.003$ & 0.0146 \\
$\mathrm{C}$ & -9.20 & 8.69 & $<0.0001$ \\
$\mathrm{AB}$ & -22.25 & 50.79 & 0.9383 \\
$\mathrm{AC}$ & 0.32 & $6.300 \mathrm{E}-0.003$ & 0.4034 \\
$\mathrm{BC}$ & -3.56 & 0.76 & 0.0001 \\
$\mathrm{~A}^{2}$ & 24.27 & 35.42 & $<0.0001$ \\
$\mathrm{~B}^{2}$ & -34.07 & 125.67 & 0.1138 \\
$\mathrm{C}^{2}$ & -5.27 & 3.00 & $<0.0001$ \\
\hline
\end{tabular}

Table 5. ANOVA results for pectin lyase activity

\begin{tabular}{llllll}
\hline Source & $\begin{array}{l}\text { Sum of } \\
\text { squares }\end{array}$ & DF & Mean square & F- value & $\begin{array}{l}\text { Probability } \\
(\mathrm{P})>\mathrm{F}\end{array}$ \\
\hline Model & 3103.18 & 9 & 344.80 & 4.85 & 0.0107 significant \\
Residual & 710.97 & 10 & 71.10 & & \\
Lack of fit & 680.35 & 5 & 136.07 & 22.22 & 0.0020 significant \\
Pure error & 30.61 & 5 & 6.12 & & \\
Corrected total & 3814.15 & 19 & & & \\
\hline
\end{tabular}

$\mathrm{R}^{2}$ : 0.8136, Adj. $\mathrm{R}^{2}$ : 0.6458, Adeq. Precision; 6.955

Table 6. Estimates of the model regression for pectin lyase activity

\begin{tabular}{lccc}
\hline Source & Parameter estimate & F- value & $\begin{array}{c}\text { Probability } \\
(\mathrm{P})>\mathrm{F}\end{array}$ \\
\hline Intercept & & & 0.0107 \\
$\mathrm{~A}$ & 26.26 & 4.85 & 0.3678 \\
$\mathrm{~B}$ & -2.15 & 0.89 & 0.0643 \\
$\mathrm{C}$ & -4.74 & 4.32 & 0.0008 \\
$\mathrm{AB}$ & -10.72 & 22.08 & 0.4848 \\
$\mathrm{AC}$ & -2.16 & 0.53 & 0.4587 \\
$\mathrm{BC}$ & 2.30 & 0.59 & 0.1880 \\
$\mathrm{~A}^{2}$ & 4.21 & 2.00 & 0.0048 \\
$\mathrm{~B}^{2}$ & -8.01 & 12.99 & 0.9082 \\
$\mathrm{C}^{2}$ & 0.26 & 0.014 & 0.6623 \\
\hline
\end{tabular}


The significance of the model terms can be revealed by $p$-values [26]. Model terms with p-values less than 0.05 are important. In this situation, $B, C, B C, A^{2}$ and $C^{2}$ are important model terms for endo pectinase activity. The linear and quadratic effects of the yeast extract concentration $\left(C\right.$ and $\left.C^{2}\right)$ and the quadratic effect of the wheat bran concentration $\left(A^{2}\right)(\mathrm{P}<0.0001)$ were more significant than the other factors. The effect of interaction between $\left(\mathrm{NH}_{4}\right)_{2} \mathrm{SO}_{4}$ and the yeast extract concentration $(B C)$ (probability coefficient $\mathrm{P}=0.0001)$ was highly important. The linear effect of $\left(\mathrm{NH}_{4}\right)_{2} \mathrm{SO}_{4}$ concentration $(B)$ (probability coefficient $\mathrm{P}=0.0146$ ) was significant. The other terms had no significance. $C$ and $A^{2}$ were significant model terms in the pectin lyase activity. The linear effect of yeast extract concentration $(C)(\mathrm{P}=0.0008)$ was an important factor. In addition, the quadratic effect of wheat bran concentration $\left(A^{2}\right)(\mathrm{P}=0.0048)$ was significant.

Generally, it is important to make sure that the chosen model provides an appropriate approach to the actual system. The adequacy of a model can be judged using the diagnostic plots such as the predicted versus actual value plot (Figures 1a and 2a) [27]. When Figures 1a and 2a are examined, it was understood that there was a linear relationship between the predicted and actual values and models were adequate [25]. The correlation coefficients between the actual and predicted values were 0.9820 and 0.9020 for the endopectinase activity and pectin lyase activity, respectively. Higher values of the correlation coefficient justify a perfect relation between the independent variables [24]. The R-value indicates good agreement between the calculated and observed activities in the experimental range. The experimental activity values were in close agreement with the activity values obtained using RSM. The residual plots were investigated using an approximate model. The normal probability and studentized residuals graphs are illustrated in Figures $1 \mathrm{~b}$ and $2 \mathrm{~b}$. The normal probability graph shows whether the residuals follow a normal distribution and in this case the points lie close to a straight line [28] describing the effectiveness of model [29]. As can be seen from Figures $1 b$ and $2 b$, s-shaped curve did not form. This shows that no response transformation was required, and that there was no obvious issue with normality [28]. Figures $1 \mathrm{c}$ and $2 \mathrm{c}$ present the perturbation plots that show the effect of each of the independent variables on the endo-pectinase activity (R1) and pectin lyase activity (R2). 


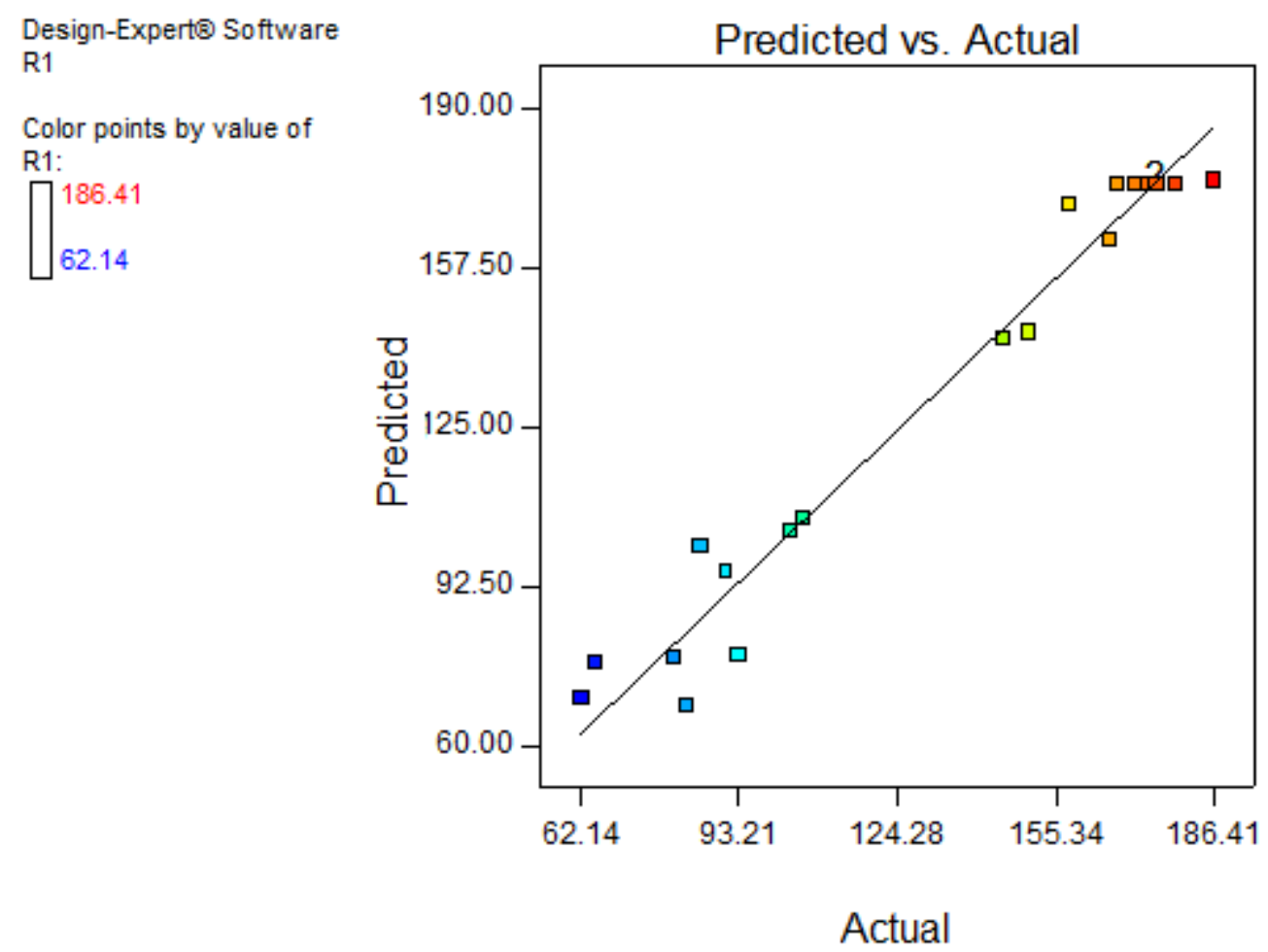

(a)

Design-Experte Software R1

Color points by value of R1:

$\prod_{62.14}^{186.41}$

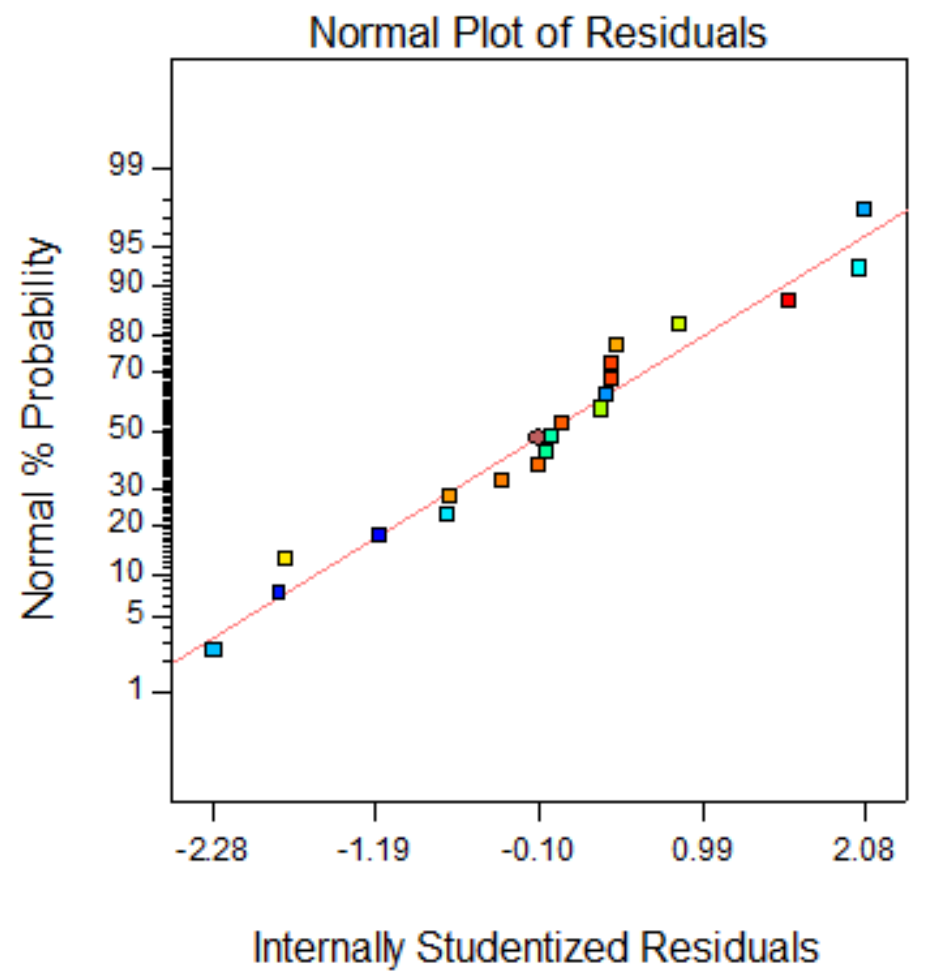

(b) 


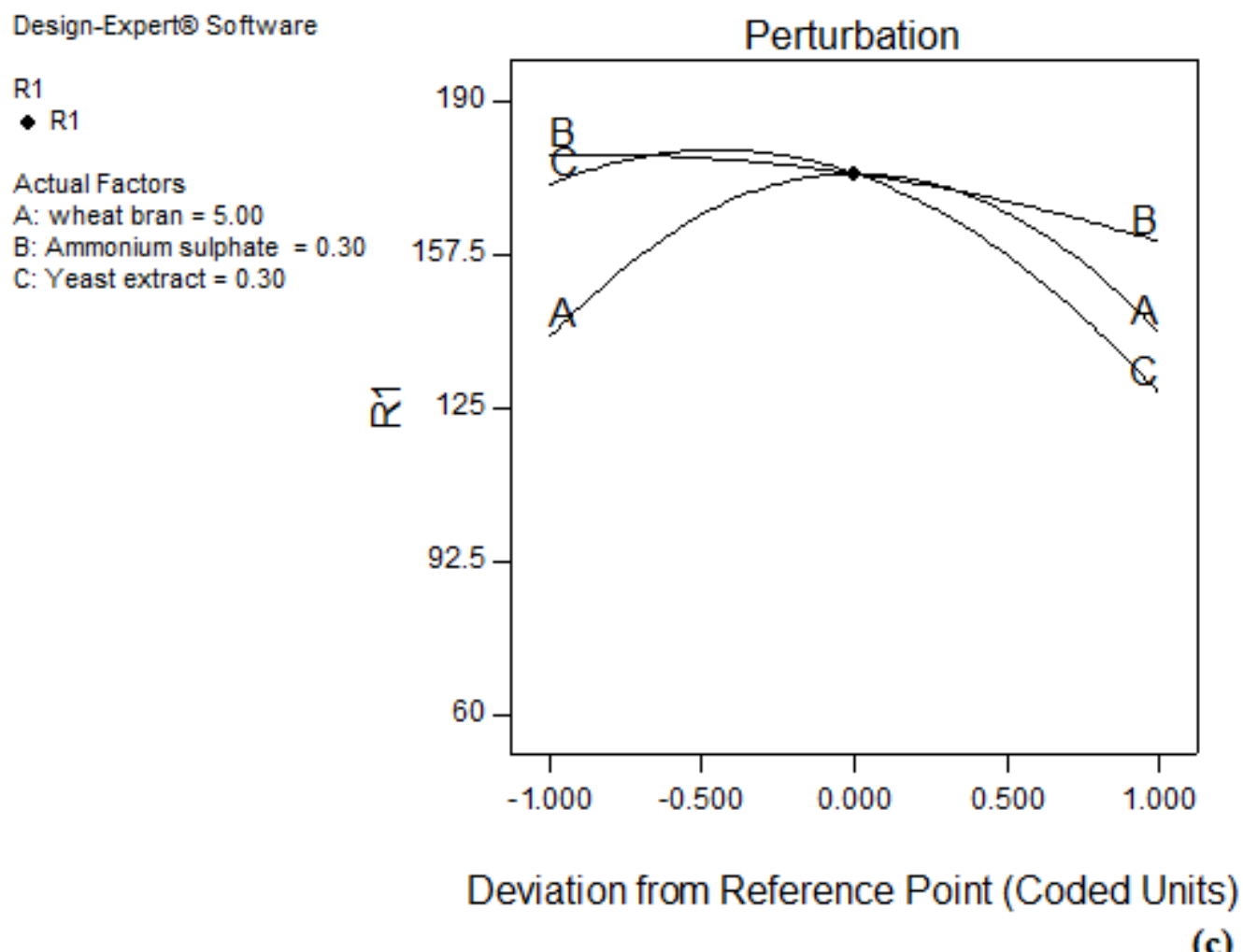

(c)

Figure 1. The actual data versus predicted data (a), the normal probability and studentized residuals graph (b) for endo-pectinase activity $(R 1)$ and perturbation plot showing the effect of each of the independent variables on endo-pectinase activity $(R I)(c)$

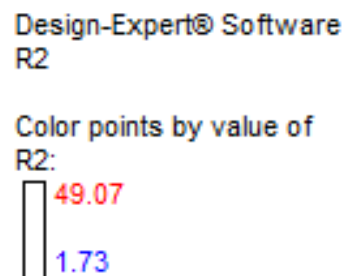

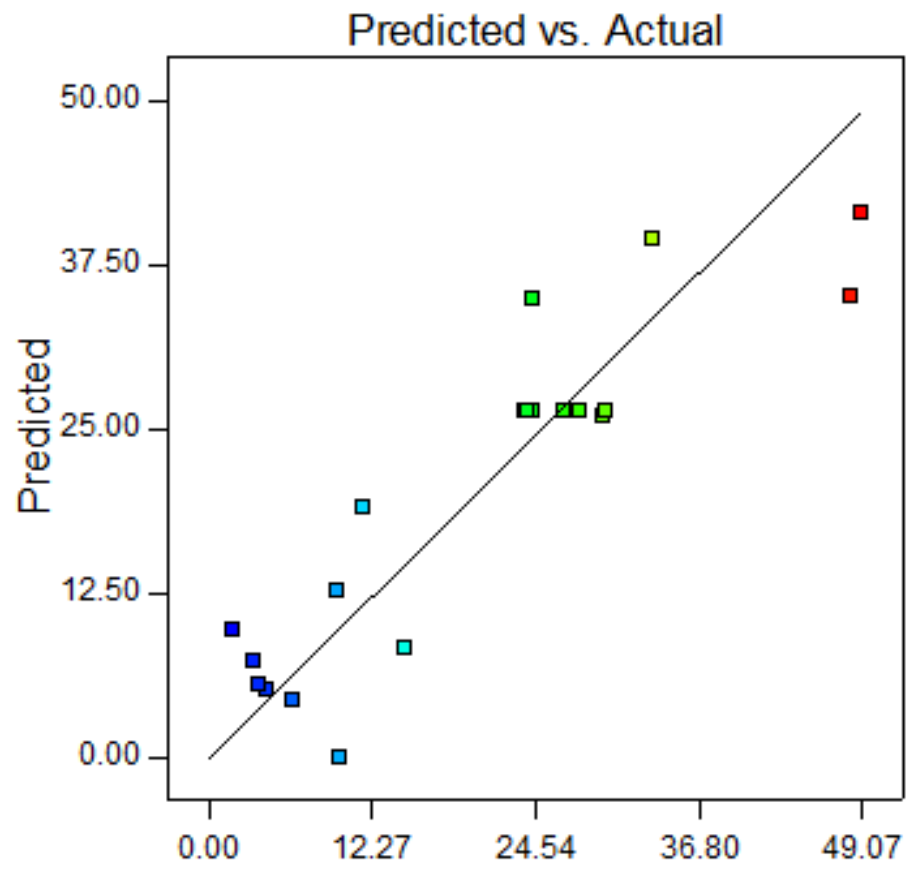

Actual (a) 
Design-Expertis Software

R2

Color points by value of

R2:

$\prod_{1.73}^{49.07}$

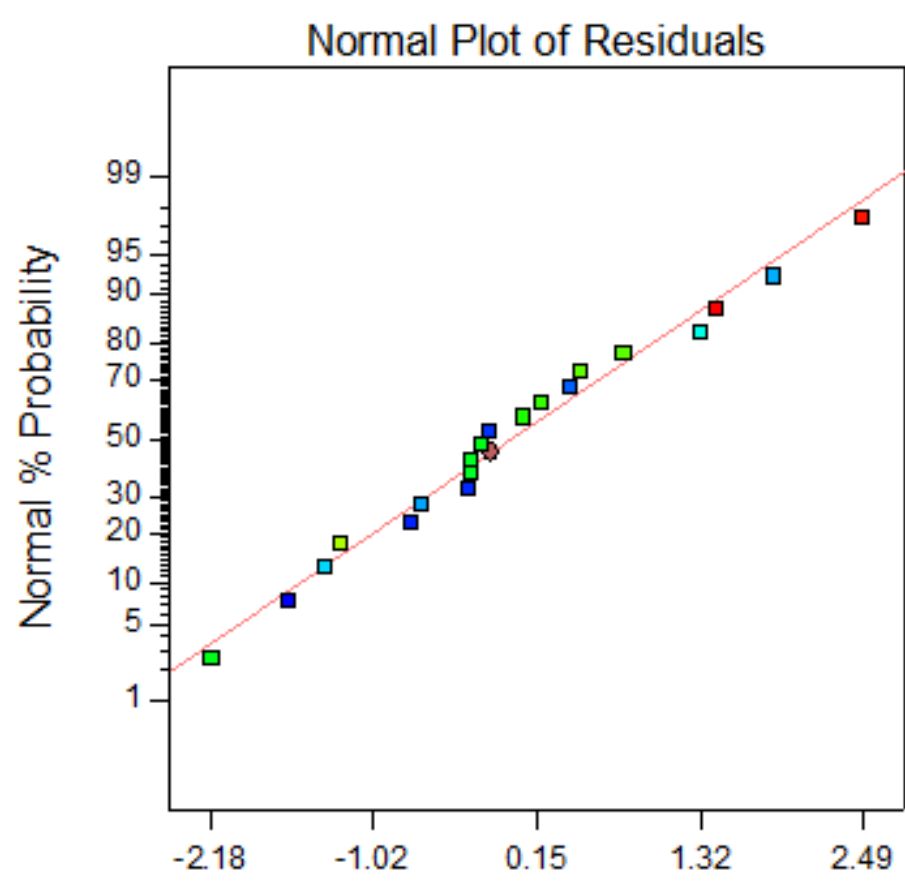

Internally Studentized Residuals

(b)

Design-Experte Software

\section{$\mathrm{R} 2$}

- R2

Actual Factors

A: wheat bran $=5.00$

B: Ammonium sulphate $=0.30$

C: Yeast extract $=0.30$

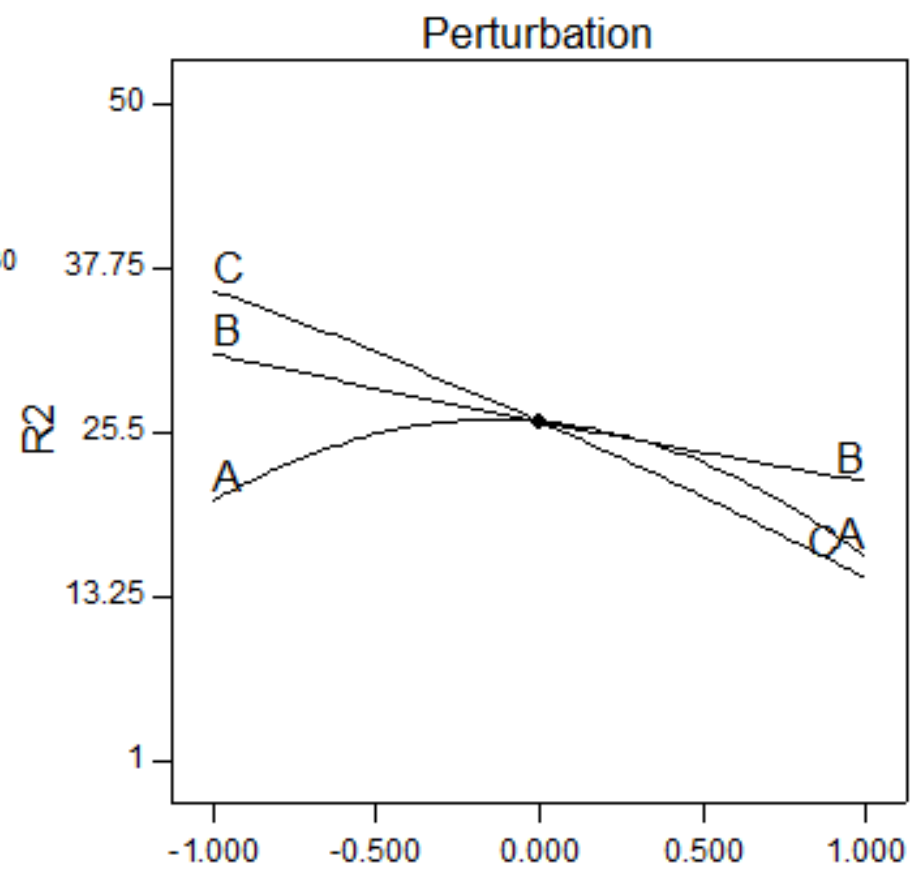

Deviation from Reference Point (Coded Units)

(c)

Figure 2. The actual data versus predicted data (a), the normal probability and studentized residuals graph (b) for pectin lyase activity $(R 2)$ and perturbation plot showing the effect of each of the independent variables on pectin lyase activity $(R 2)(c)$ 
The regression formula obtained from the RSM analysis can be illustrated with 3-D and 2-D curves. These curves are plotted using a statistically suitable model to reveal the optimum levels of each element required for maximum enzyme synthesis and to comprehend the interaction of media elements [20]. Thus, with these 3-D and 2-D curves, finding the optimal variable concentrations is also very simple and convenient [30]. All plots are presented in Figures 3-8. In all plots, while a variable was maintained to zero (0) level, the effect of the two factors was presented. The pectin lyase and endo-pectinase activities were found to increase when low levels of $B$ and $C$ and a moderate level of $A$ were used. The relatively circular nature of the 2-D plots in Figures 3 and 4 is evidence that there was almost no interaction between $A$ and $B$ and $A$ and $C$. The 2-D curves in Figure 5 showed that there was a mutual interaction between $B$ and $C$ for the endo-pectinase activity.
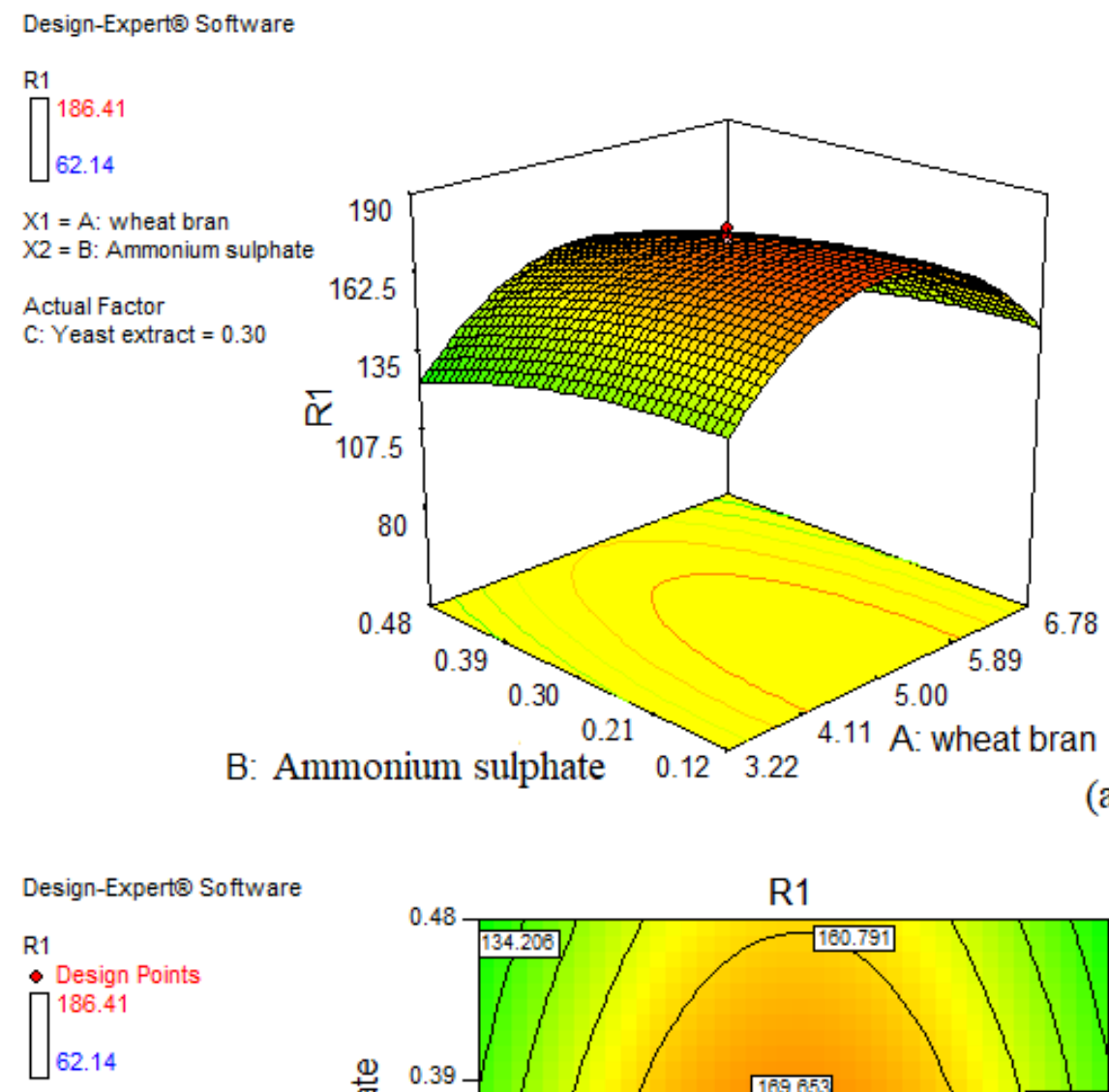

$\mathrm{X} 1=\mathrm{A}$ : wheat bran $\mathrm{X} 2=\mathrm{B}$ : Ammonium sulphate

Actual Factor

C: Yeast extract $=0.30$

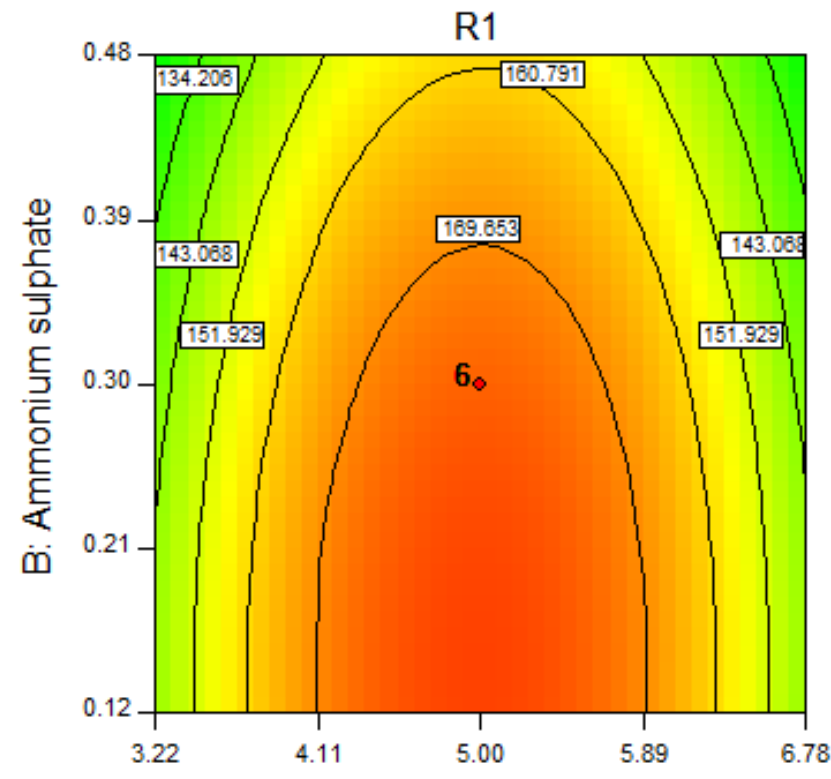

A: wheat bran

Figure 3. Response surface plots for endo-pectinase activity $(R 1)$ 
Design-Expert(8) Software

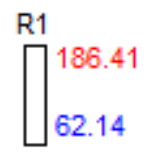

$\mathrm{X} 1=\mathrm{A}:$ wheat bran $\mathrm{X} 2=\mathrm{C}$ : Yeast extract

Actual Factor

B: Ammonium sulphate $=0.30$

$$
\overline{\underline{x}}
$$

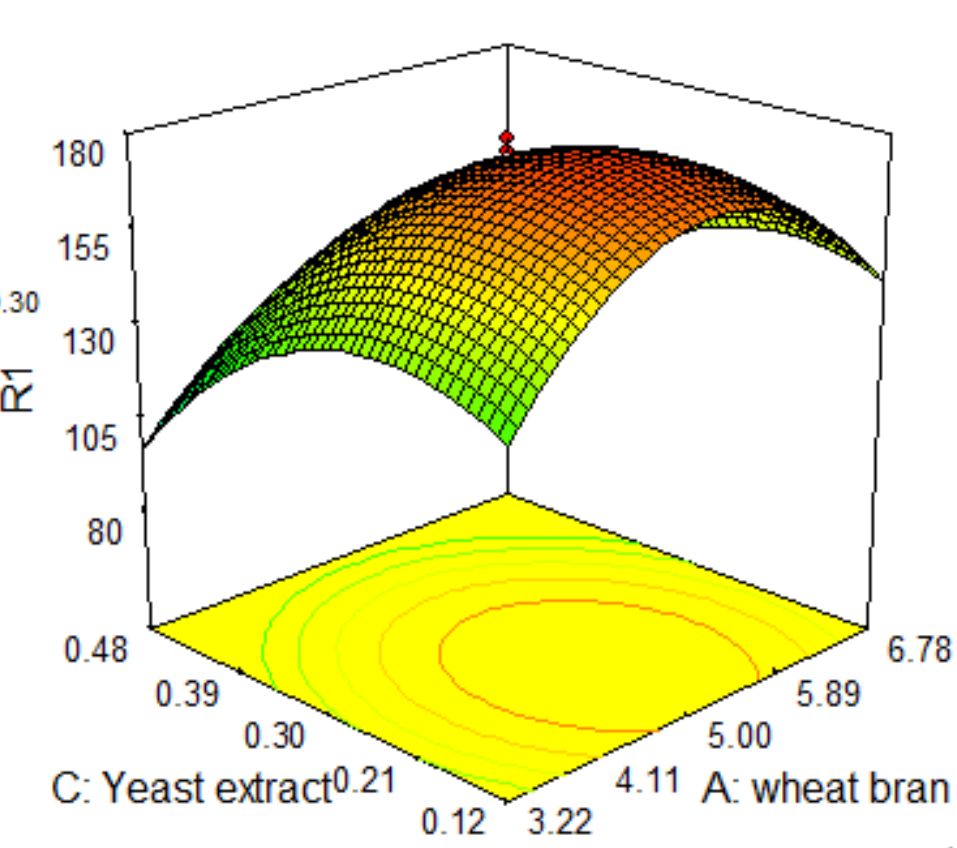

(a)

Design-Expertis Software

R1

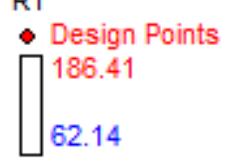

$\mathrm{X} 1=\mathrm{A}:$ wheat bran $\mathrm{X} 2$ = C: Yeast extract

Actual Factor

B: Ammonium sulphate $=0.30$

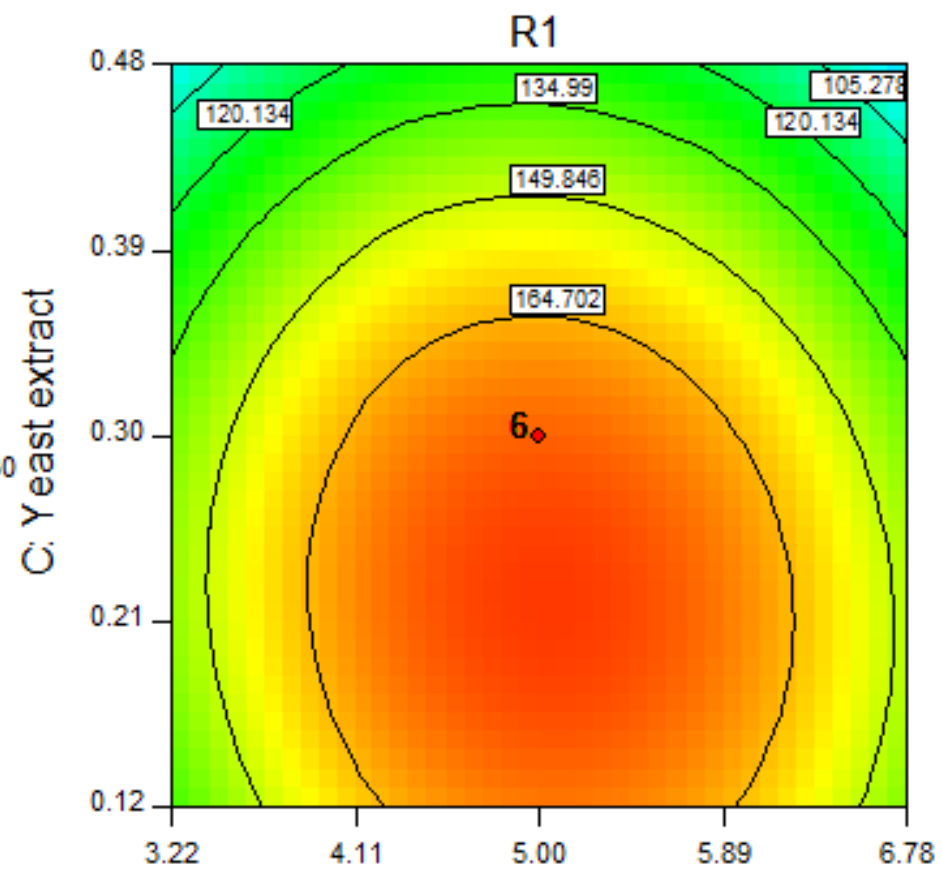

A: wheat bran

(b)

Figure 4. Response surface plots for endo-pectinase activity (R1) 
Design-Expert(8) Software

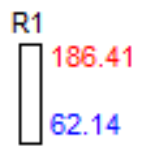

$\mathrm{X} 1=\mathrm{B}:$ Ammonium sulphate $\mathrm{X} 2=\mathrm{C}$ : Yeast extract

Actual Factor

A: wheat bran $=5.00$

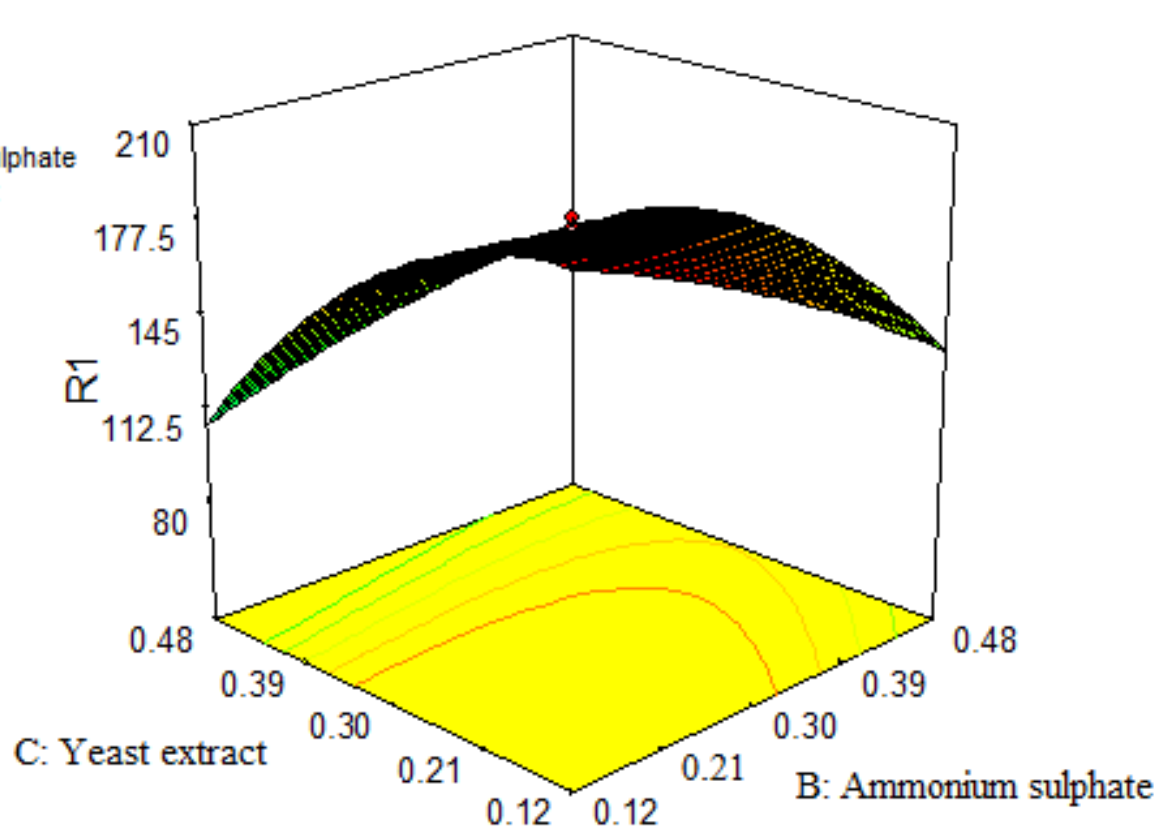

(a)

Design-Experti Software

R1

- Design Points

186.41

62.14

$\mathrm{X} 1=\mathrm{B}:$ Ammonium sulphate $\mathrm{X} 2=\mathrm{C}:$ Yeast extract

Actual Factor

A: wheat bran $=5.00$

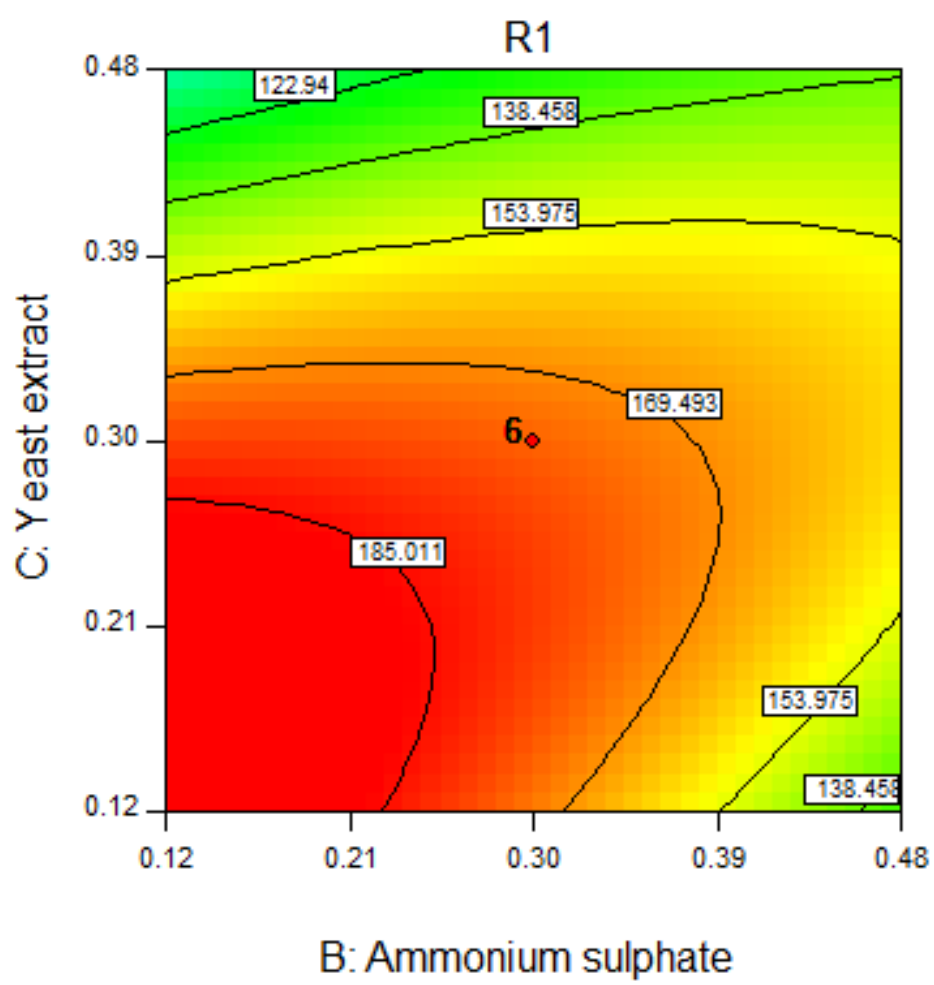

(b)

Figure 5. Response surface plots for endo-pectinase activity (RI) 
Design-Expert(8) Software

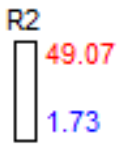

$\mathrm{X} 1=\mathrm{A}$ : wheat bran

$\mathrm{X} 2$ = B: Ammonium sulphate

Actual Factor

C: Yeast extract $=0.30$

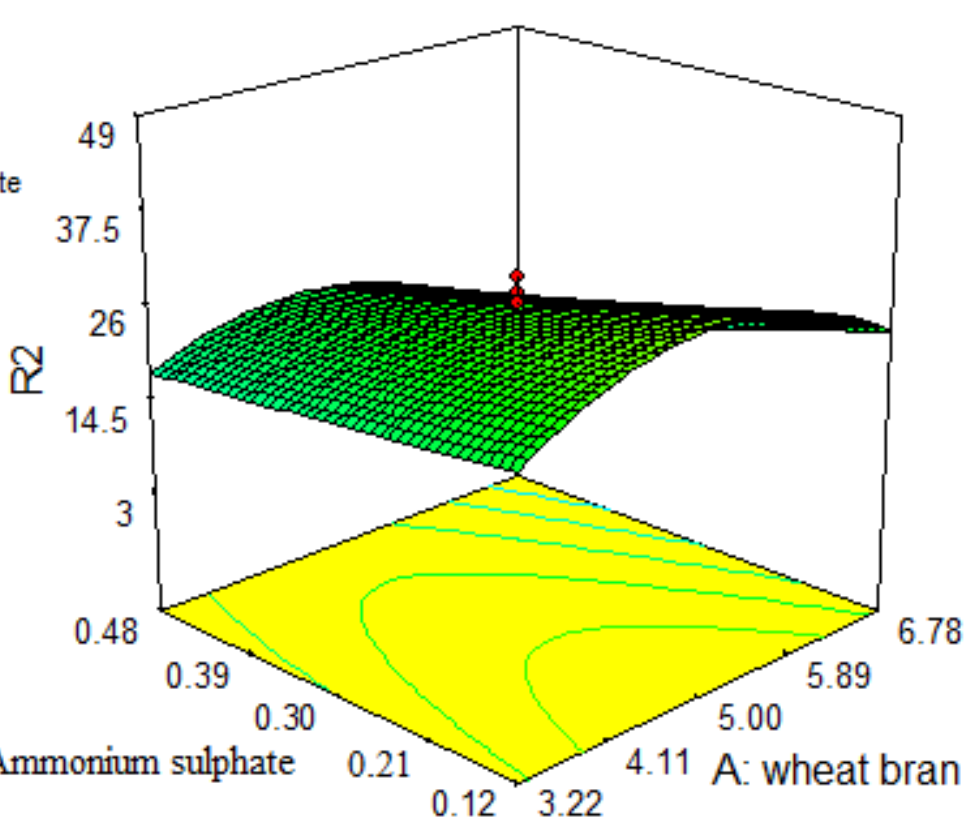

(a)

Design-Expert(2) Software

$\mathrm{R} 2$

- Design Points

$\prod_{1.73}^{49.07}$

$\mathrm{X} 1=\mathrm{A}:$ wheat bran

$\mathrm{X} 2=\mathrm{B}$ : Ammonium sulphate

Actual Factor

C: Yeast extract $=0.30$

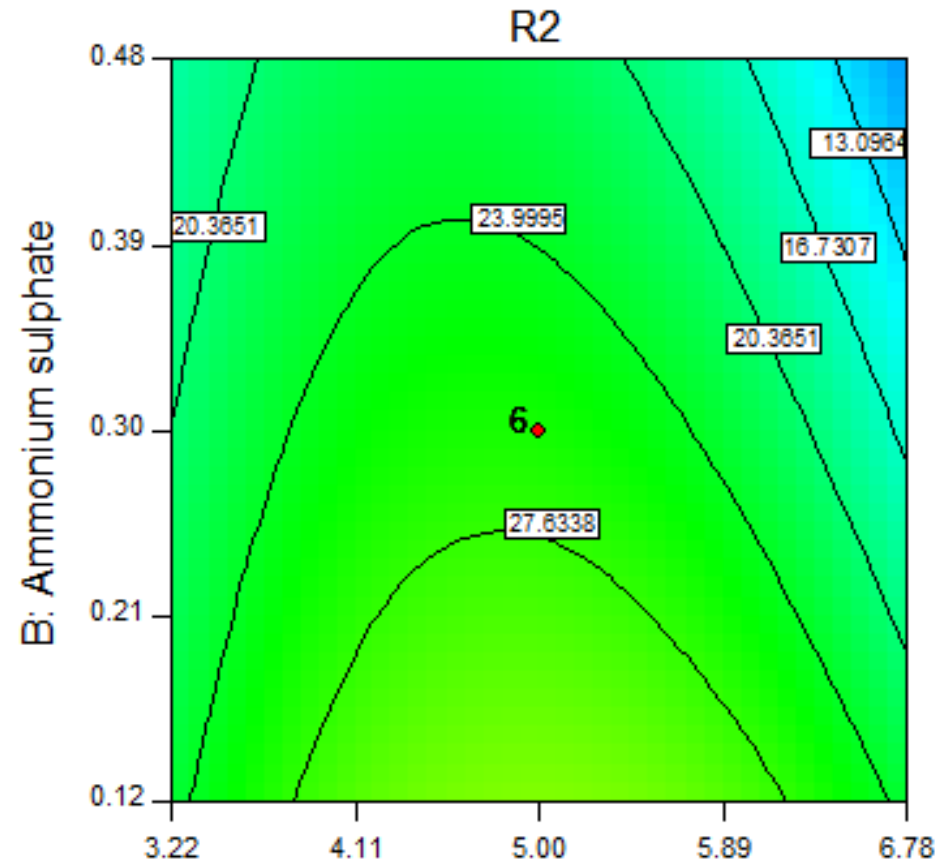

A: wheat bran

(b)

Figure 6. Response surface plots for pectin lyase activity (R2) 
Design-Experte Software

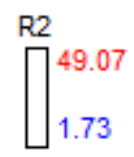

$\mathrm{X} 1=\mathrm{A}:$ wheat bran

$\mathrm{X} 2=\mathrm{C}:$ Yeast extract

Actual Factor

B: Ammonium sulphate $=0.30$

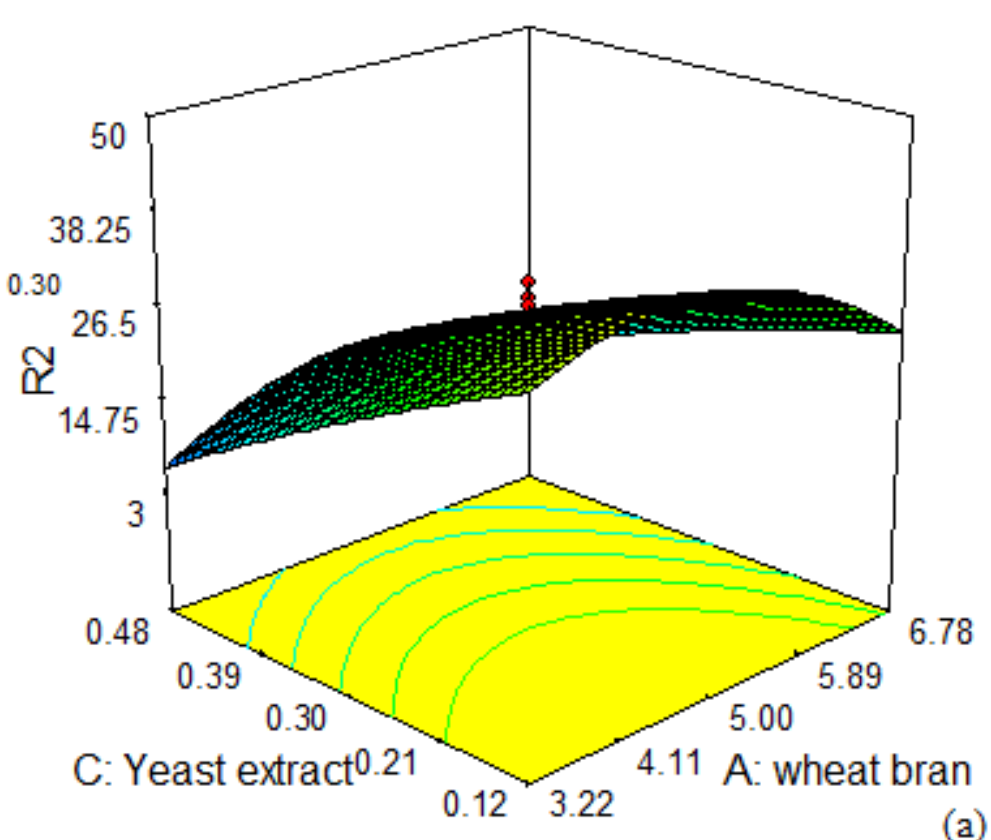

Design-Expert(8) Software

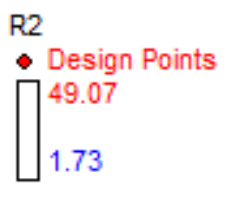

$\mathrm{X} 1=\mathrm{A}:$ wheat bran $\mathrm{X} 2$ = $\mathrm{C}$ : Yeast extract

Actual Factor
B: Ammonium sulphate $=0.30 \stackrel{+}{\sigma}$

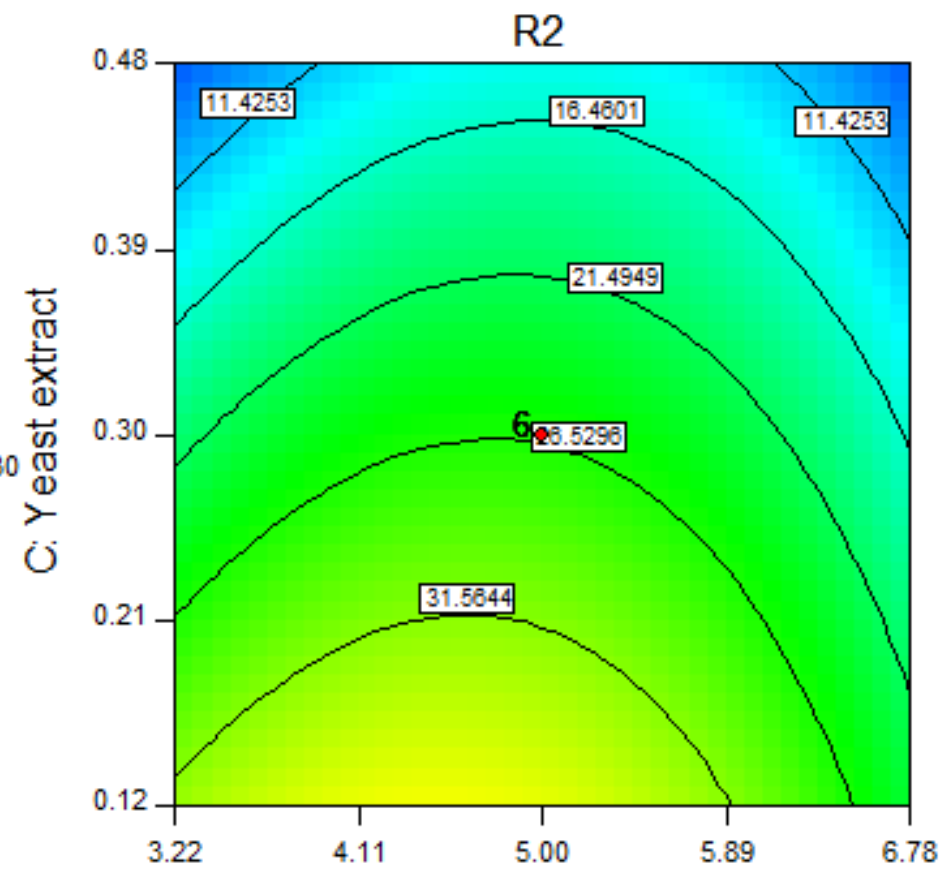

A: wheat bran

(a) 
Design-Experte Software

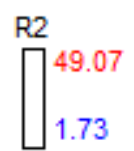

$\mathrm{X} 1$ = B: Ammonium sulphate $\mathrm{X} 2$ = C: Yeast extract

Actual Factor

A: wheat bran $=5.00$

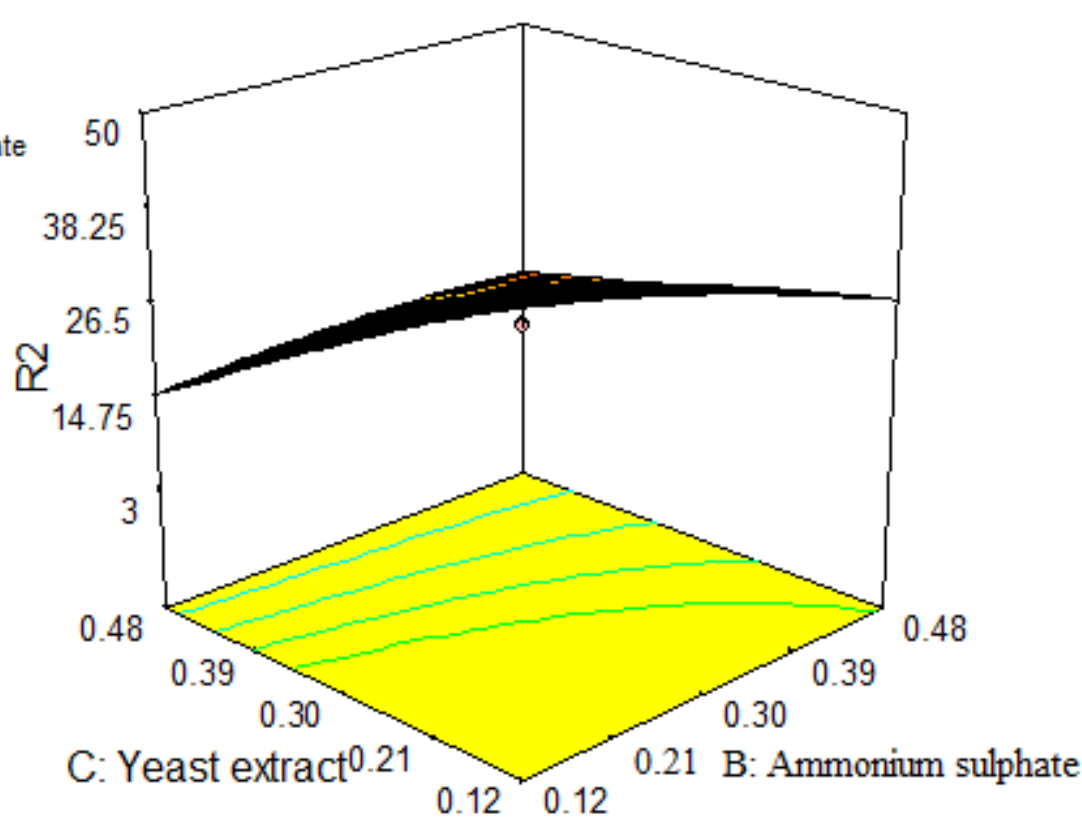

(a)

Design-Expert(8) Software

R2

$\bullet$ Design Points
$\prod_{1.73}^{49.07}$

$\mathrm{X} 1=\mathrm{B}:$ Ammonium sulphate $\mathrm{X} 2=\mathrm{C}:$ Yeast extract

Actual Factor

A: wheat bran $=5.00$

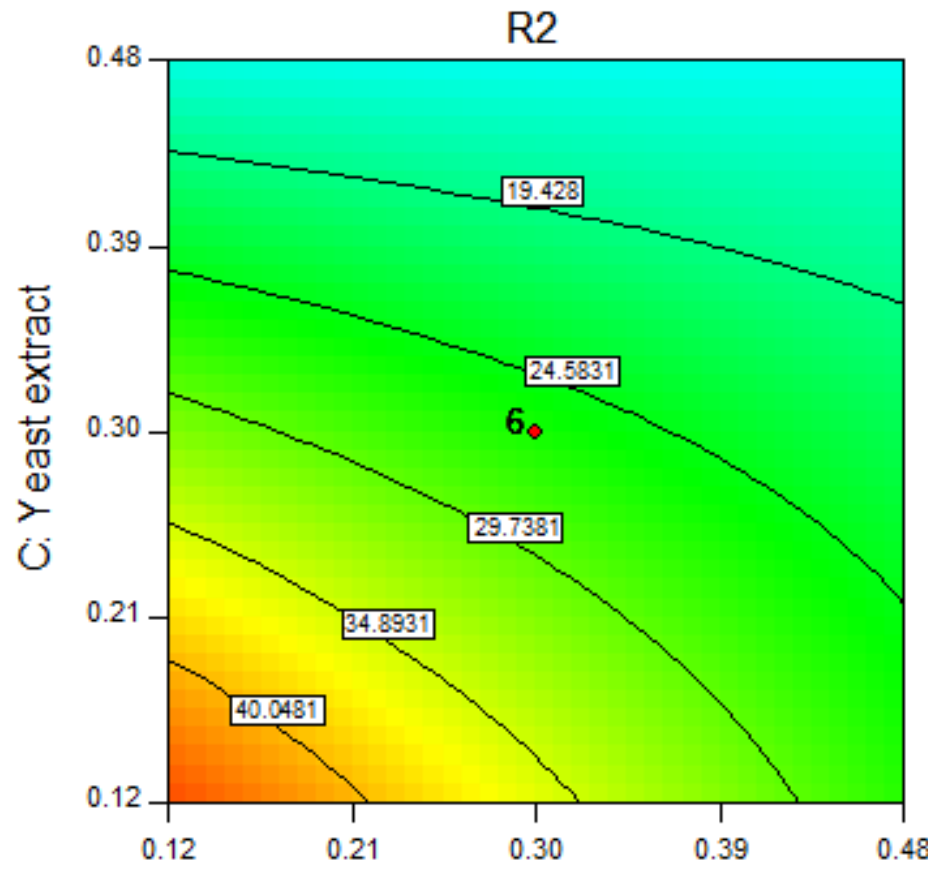

B: Ammonium sulphate

(b)

Figure 8. Response surface plots for pectin lyase activity $(R 2)$

To obtain the maximum endo-pectinase and pectin lyase activities of 199.21 and $45.37 \mathrm{U} / \mathrm{mL}$, respectively, the optimum conditions were determined as $4.74 \% \mathrm{w} / \mathrm{v}$ wheat bran, $0.12 \%$ yeast extract and $0.12 \%$ $\left(\mathrm{NH}_{4}\right)_{2} \mathrm{SO}_{4}$ with a desirability function of 0.9798 (Figure 9). The closer the desirability value is to 1 [31], the more suitable the levels of the media components selected to achieve maximum activity. 

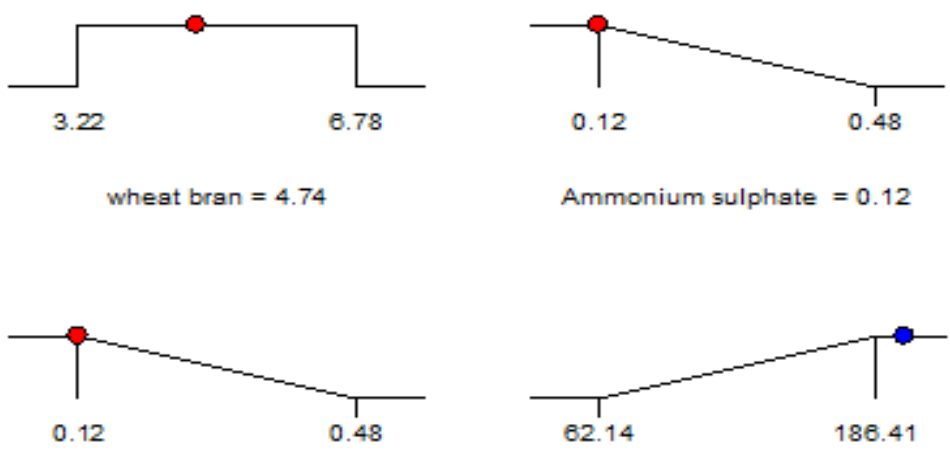

Yeast extract $=0.12$

$\mathrm{R} 1=199.21$

Desirability $=0.980$

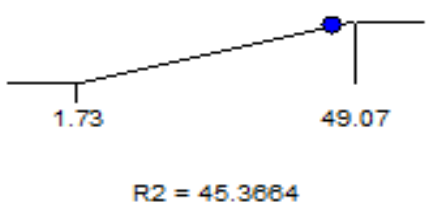

Figure 9. Desirability ramp of endo-pectinase and pectin lyase production for numerical optimization of three independent variables

The most important components of bacteria's biological process medium are carbon and nitrogen [32]. The excess wheat bran in the fermentation media reduced the enzyme production. When a low amount of nitrogen was used in the fermentation medium, enzyme production was found to increase. The excessive addition of the nitrogen source can decrease enzyme production. This can be due to the fact that an optimal carbon/nitrogen $(\mathrm{C} / \mathrm{N})$ is necessary for maximum enzyme production [33]. The $\mathrm{C} / \mathrm{N}$ ratio $(\mathrm{C} / \mathrm{N})$ is a critical factor that influence cell growth and the yield of the product during fermentation [34]. The $\mathrm{C} / \mathrm{N}$ ratio used (the highest activities were obtained) in this study was approximately 20 with $4.74 \%$ wheat bran and $0.24 \%$ nitrogen $(0.12 \%$ for ammonium sulphate $+0.12 \%$ for yeast extract $=0.24 \%)$. In a previous study conducted by Anvari and Khayati [35] it was stated that the highest pectinase production was obtained at a $\mathrm{C} / \mathrm{N}$ ratio of 10:1 and that a very high or very low $\mathrm{C} / \mathrm{N}$ ratio provided relatively less enzyme activity. However, enzyme production at a $\mathrm{C} / \mathrm{N}$ ratio of 10:1 was found to be no different from that of the $\mathrm{C} / \mathrm{N}$ ratio of 20:1. Thus, it can be said that the tolerable limit of $\mathrm{C} / \mathrm{N}$ for pectinase enzyme production is not too narrow. An excessive increase in the $\mathrm{C} / \mathrm{N}$ ratio decreased enzyme production. Nair and Panda [36] determined that the highest pectinase activity was achieved with $\mathrm{C} / \mathrm{N}$ ratios between 10 and 15 .

\section{CONCLUSIONS}

In this study, wheat bran, which is an agricultural waste, was transformed into value-added products, namely pectin lyase and endo- pectinase by fermentation. The production of pectin lyase and endopectinase from wheat bran by Bacillus pumilus was optimized by RSM. This methodology has been successfully applied to clutch effects and the interaction between components and. While $B, C, B C, A^{2}$ and $C^{2}$ are important model terms for endo-pectinase activity, $C$ and $A^{2}$ are significant model terms in pectin lyase activity. The $\mathrm{C} / \mathrm{N}$ ratio used in this study was approximately 20 with $4.74 \%$ wheat bran and $0.24 \%$ nitrogen $(0.12 \%$ for ammonium sulphate $+0.12 \%$ for yeast extract $=0.24 \%)$. With the high activity values obtained, it was determined that these enzymes have a great potential especially in industrial applications such as the fruit juice and textile industries.

\section{ACKNOWLEDGMENTS}

This paper includes a part of Ph.D thesis data of Ozlem TEPE. This work was financially supported by the Firat University Scientific Research Projects Management Unit (FUBAP) (Grant no. FÜBAP 1674). 


\section{CONFLICTS OF INTEREST}

No conflict of interest was declared by the authors.

\section{REFERENCES}

[1] Pedrolli, D.B., Monteiro, A.C., Gomes, E., Carmona, E.C., "Pectin and pectinases: production, characterization and industrial application of microbial pectinolytic enzymes". Open Biotechnol. J., 3: 9-18, (2009).

[2] Jayani, R.S., Saxena, S., Gupta, R., "Microbial pectinolytic enzymes: A review", Process Biochem., 40: 2931-2944, (2005).

[3] Alkorta, I., Garbisu, C., Llama, M.J., Serra, J.L., "Industrial applications of pectic enzymes: a review", Process Biochem., 33: 21-28, (1998).

[4] Kashyap, D.R., Vohra, P.K., Chopra, S., Tewari, R., "Applications of pectinases in the commercial sector: a review”, Bioresource Technol., 77(3): 215-227, (2001).

[5] Kertesz, Z., "A new method for enzymic clarification of unfermented apple juice. US patent no. 1.932.833", New York State Agricultural Experimentation Station (Geneva) Bull. No. 689, (1930).

[6] El-Sheekh, M.M., Ismail, A.-m.S., El-Abd, M.A., Hegazy, E.M., El-Diwany, A.I., "Effective technological pectinases by Aspergillus carneus NRC1 utilizing the Egyptian orange juice industry scraps", Int. Biodeter. Biodegr., 63: 12-18, (2009).

[7] Baracat-Pereira, M.C., Coelho, J.L.C., Silva, D.O., "Production of pectin lyase by Penicillium griseoroseum cultured on sucrose and yeast extract for degumming of natural fibres", Lett. Appl. Microbiol., 18(3): 127-129, (1994).

[8] Prathyusha, K., Suneetha, V., "Bacterial pectinases and their potent biotechnological application in fruit processing/juice production industry: a review". J. Phytol., 3(6): 16-19, (2011).

[9] Mojsov, K., "The effects of different carbon sources on biosynthesis of pectinolytic enzymes by Aspergillus niger", ATI -Appl. Technol. Inno., 3(3): 23-29, (2010).

[10] Naidu, G.S.N., Panda, T., "Production of pectolytic enzymes -a review", Bioprocess Eng., 19: 355-361, (1998).

[11] Oumer, O.J., Abate, D., "Comparative studies of pectinase production by Bacillus subtilis strain Btk 27 in submerged and solid-state fermentations", Biomed Res. Int., 2018: 1514795, (2018).

[12] Demir, H., Tar1, C., "Valorization of wheat bran for the production of polygalacturonase in SSF of Aspergillus sojae", Ind. Crop Prod., 54: 302-309, (2014).

[13] Fang, T.J., Liao, B.-C., Lee, S.-C., "Enhanced production of xylanase by Aspergillus carneus M34 in solid-state fermentation with agricultural waste using statistical approach", New Biotechnol., 27(1): 25-32, (2010).

[14] Castilho, L.R., Medronho, R.A., Alves, T.L.M., "Production and extraction of pectinases obtained by solid-state fermentation of agroindustrial residues with Aspergillus niger", Bioresource Technol., 71(1): 45-50, (2000). 
[15] Pandey, A., Soccol, C.R., Mitchell, D., "New developments in solid state fermentation: Ibioprocesses and products", Process Biochem., 35: 1153-1169, (2000).

[16] Pandey, A., "Solid-state fermentation”, Biochem. Eng. J., 13: 81-84, (2003).

[17] Díaz, A.B., de Ory, I., Caro, I., Blandino, A., "Enhance hydrolytic enzymes production by Aspergillus awamori on supplemented grape pomace", Food Bioprod. Process, 90: 72-78, (2012).

[18] Kumar, R.S., Ananthan, G., Prabhu, A.S., "Optimization of medium composition for alkaline protease production by Marinobacter $s p$. GA CAS9 using response surface methodology-A statistical approach", Biocatal. Agric. Biotechnol., 3: 191-197, (2014).

[19] Goncalves, D.B., Teixeira, J.A., Bazzolli, D.M.S., Queiroz, M.V., Araujo, E. F., "Use of response surface methodology to optimize production of pectinases by recombinant Penicillium griseoroseum T20", Biocatal. Agric. Biotechnol., 1: 140-146, (2012).

[20] Tepe, O., Dursun, A.Y., "Exo-pectinase production by Bacillus pumilus using different agricultural wastes and optimizing of medium components using response surface methodology", Environ. Sci. Pollut. Res., 21: 9911-9920, (2014).

[21] Nedjma, M., Hoffmann, N., Belarbi, A., "Selective and sensitive detection of pectin lyase activity using a colorimetric test: application to the screening of microorganisms possessing pectin lyase activity", Anal. Biochem., 291: 290-296, (2001).

[22] Tepe, O., Dursun, A.Y., "Bioprocess parameters and oxygen transfer characteristics in pectin lyase production by Bacillus pumilus", Fresen. Environ. Bull., 26(8): 5082-5091, (2017).

[23] Tuttobello, R., Mill, P.J., "The pectic enzymes of Aspergillus niger 1. The production of active mixtures of pectic enzymes", Biochem. J., 79: 51-57, (1961).

[24] Elibol, M., "Response surface methodological approach for inclusion of perfluorocarbon in actinorhodin fermentation medium", Process Biochem., 38: 667-673, (2002).

[25] Manan, T.S.B.A., Khan, T., Sivapalan, S., Jusoh, H., Sapari, N., Sarwono, A., Ramli, R.M., Harimurti, S., Beddu, S., Sadon, S.N., Kamal, N.L.M., Malakahmad, A., "Application of response surface methodology for the optimization of polycyclic aromatic hydrocarbons degradation from potable water using photo-Fenton oxidation process", Sci. Total Environ., 665: 196-212, (2019).

[26] Li, H., van den Driesche, S., Bunge, F., Yang, B., Vellekoop, M.J., “Optimization of on-chip bacterial culture conditions using the Box-Behnken design response surface methodology for faster drug susceptibility screening", Talanta, 194: 627-633, (2019).

[27] Gönen, F., Aksu, Z., "Single and binary dye and heavy metal bioaccumulation properties of Candida tropicalis: Use of response surface methodology (RSM) for the estimation of removal yields", J. Hazard. Mater., 172: 1512-1519, (2009).

[28] Tanyildizi, M.Ş., "Modeling of adsorption isotherms and kinetics of reactive dye from aqueous solution by peanut hull", Chem. Eng. J., 168: 1234-1240, (2011).

[29] Abdel Wahab, W.A., Ahmed, S.A., "Response surface methodology for production, characterization and application of solvent, salt and alkali-tolerant alkaline protease from isolated fungal strain Aspergillus niger WA 2017”, Int. J. Biol. Macromol., 115: 447-458, (2018). 
[30] Gönen, F., Aksu, Z., "Use of response surface methodology (RSM) in the evaluation of growth and copper (II) bioaccumulation properties of Candida utilis in molasses medium", J. Hazard. Mater., 154: 731-738, (2008).

[31] Unuofin, J.O., Okoh, A.I., Nwodo, U.U., "Utilization of agroindustrial wastes for the production of laccase by Achromobacter xylosoxidans HWN16 and Bordetella bronchiseptica HSO16", J. Environ. Manage., 231: 222-231, (2019).

[32] Ulhiza, T.A., Puad, N.I.M., Azmi, A.S., "Optimization of culture conditions for biohydrogen production from sago wastewater by Enterobacter aerogenes using response surface methodology", Int. J. Hydrogen Energy, 43: 22148-22158, (2018).

[33] Panesar, P.S., Chavan, Y., Chopra, H.K., Kennedy, J.F., "Production of microbial cellulose: Response surface methodology approach”, Carbohyd. Polym., 87: 930-934, (2012).

[34] Xiao, R., Li, X., Zheng, Y., "Enzyme production by a fungoid marine protist Thraustochytrium striatum", Eur. J. Protistol., 66: 136-148, (2018).

[35] Anvari, M., Khayati, G., "The effect of citrus pulp type on pectinase production in solid-state fermentation: Process evaluation and optimization by Taguchi design of experimental (DOE) methodology", J. BioSci. Biotech., 3(3): 227-233, (2014).

[36] Nair, S.R., Panda, T., "Statistical optimization of medium components for improved synthesis of pectinase by Aspergillus niger", Bioprocess Eng., 16: 169-173, (1997). 